\title{
Free and Lipid Inositol, Sorbitol and Sugars in Sciatic Nerve Obtained Post-Mortem from Diabetic Patients and Control Subjects
}

\author{
J.A. Mayhew ${ }^{1}$, K. R. W.Gillon² and J. N. Hawthorne', \\ ${ }^{1}$ Department of Clinical Chemistry, City Hospital, ${ }^{2}$ Department of Biochemistry, University Hospital and Medical School, Nottingham, UK.
}

\begin{abstract}
Summary. Sciatic nerves removed post-mortem from diabetic patients and normal subjects were analysed by gas chromatography for glucose, fructose, sorbitol and myo-inositol. The concentrations of free and lipid inositol were significantly lower in nerves from the diabetic than from the control group.
\end{abstract}

Concentrations of glucose, fructose and sorbitol were higher in the nerves of the diabetic patients.

Key words: Myo-inositol, sorbitol, diabetes, sciatic nerve postmortem, diabetic neuropathy.
The peripheral neuropathy seen in diabetes mellitus is more likely to be due to metabolic changes in the Schwann cell or axon than to vascular damage [1]. It has been suggested that the increased concentration of sorbitol in diabetic nerve causes osmotic damage to Schwann cells [2], though there is evidence to the contrary $[1,3]$. In experimental diabetes there is a reduced concentration of free myo-inositol in sciatic nerve [4-7]. This may be important in the development of neuropathy since inositol lipid metabolism is involved in nerve impulse conduction $[8,9]$. The deficiency of free inositol has not been reported in nerves from diabetic patients, though the concentration of inositol was significantly reduced in cerebro-spinal fluid from diabetic patients with neuropathy [10]. The combined endoneurial phosphatidylinositol/phosphatidylserine fraction was also reduced in sural nerve biopsies from three men with non-insulin-dependent diabetes [11]. On the other hand, sural nerve biopsy samples from 20 diabetic patients showed no reduction in free inositol, though only a third had raised sorbitol and fructose [12].

Since most of the evidence indicates that peripheral nerve inositol metabolism is altered in diabetes, we have measured the concentration of free and lipid inositol, sorbitol, fructose and glucose in human sciatic nerves obtained post-mortem from diabetic patients and normal subjects.

\section{Materials and Methods}

At post-mortem examination a 3-4 cm length of sciatic nerve was removed from the ischial tuberosity region within $24 \mathrm{~h}$ of death. The samples were stored at $-20^{\circ} \mathrm{C}$ if dissection could not be done imme- diately. A Nikon SMZ dissecting microscope (Projectina, Skelmorlie, Ayrshire, Scotland) was used, separate fascicles being pulled out of the gross sample at $4^{\circ} \mathrm{C}$. Epineurium and perineurium were then removed. If removal was incomplete, stringy material was seen which would not homogenize in perchloric acid. Such samples were rejected. The tissue was dried on filter paper and weighed. Samples were allocated to diabetic or control groups by reference to the medical history notes. Causes of death were not significantly different in the two groups. They were as follows: diabetic group: 12 men and 11 women, aged 46-88 years, (respiratory disease: 12 , cardiac disease: eight, cerebro-vascular disease: one, carcinoma: two); control group, ten men and five women, aged 34-94 years, (respiratory disease: eight, cardiac disease: six, carcinoma: one). Diabetes mellitus was mostly of the non-insulin-dependent type. Further details about the patients are given in Table 1 .

The nerves (wet weight $80-90 \mathrm{mg}$ ) were homogenized in $1 \mathrm{ml}$ of $0.33 \mathrm{~mol} / \mathrm{l}$ perchloric acid and centrifuged. The precipitates were

Table 1. Details of diabetic patients

\begin{tabular}{lllll}
\hline Patient & Sex & $\begin{array}{l}\text { Age at death } \\
\text { (ycars) }\end{array}$ & $\begin{array}{l}\text { Duration of } \\
\text { diabetes } \\
\text { (years) }\end{array}$ & Treatment \\
\hline 1 & M & 51 & 20 & Insulin \\
2 & M & 46 & 1 & Insulin \\
3 & M & 59 & 8 & Insulin \\
4 & F & - & - & Insulin \\
5 & M & 61 & 3 & Insulin \\
6 & F & 73 & 10 & Glibenclamide \\
7 & F & 63 & 3 & Glibenclamide \\
8 & F & 88 & 1 & Glibenclamide \\
9 & M & 64 & 7 & Glibenclamide \\
10 & M & 74 & 15 & Chlorpropramide \\
11 & F & 73 & 12 & Chlorpropramide \\
12 & M & 63 & 12 & Tolbutamide \\
13 & M & - & - & Diet \\
\hline
\end{tabular}

Information was not available for the other 10 patients 
Table 2. Free sugars and polyols, lipid inositol and protein of human sciatic nerve in diabetic patients and control subjects

\begin{tabular}{lccl}
\hline & Diabetic patients & Control subjects & $p$ \\
\hline $\begin{array}{l}\text { Free inositol } \\
(\mu \mathrm{mol} / \mathrm{g})\end{array}$ & $1.91 \pm 1.34(23)$ & $3.33 \pm 2.07(15)$ & 0.016 \\
Glucose $(\mu \mathrm{mol} / \mathrm{g})$ & $1.61 \pm 1.26(20)$ & $0.46 \pm 0.29(14)$ & 0.003 \\
Fructose $(\mu \mathrm{mol} / \mathrm{g})$ & $1.24 \pm 1.88(20)$ & $0.08 \pm 0.13(15)$ & 0.027 \\
Sorbitol $(\mu \mathrm{mol} / \mathrm{g})$ & $0.39 \pm 0.49(20)$ & $0.09 \pm 0.10(15)$ & 0.034 \\
Lipid inositol & $0.71 \pm 0.38(22)$ & $1.11 \pm 0.60(14)$ & 0.022 \\
$(\mu \mathrm{mol} / \mathrm{g})$ & & & \\
Protein $(\mathrm{mg} / \mathrm{g})$ & $52.3 \pm 10.4(23)$ & $56.0 \pm 13.1(15)$ & $\mathrm{NS}$ \\
\hline
\end{tabular}

Results expressed as mean \pm SD with number of samples in parentheses. NS $=$ not significant

homogenized again in the same way, centrifuged once more and the residue finally washed with $1 \mathrm{ml}$ of $0.33 \mathrm{~mol} / 1$ perchloric acid. The sugars and polyols in the combined supernatants were converted to trimethylsilyl ethers for estimation by gas chromatography as described previously [6]. Instead of Supelcoport, Chromosorb WHP 80/100 (Pierce Chemicals, Rockford, Illinois, USA) was used for the column. Glucose, fructose, sorbitol and myo-inositol were determined in this way.

Lipids were extracted and hydrolysed in $6 \mathrm{~mol} / 1 \mathrm{HCl}$ for the estimation of lipid inositol by the same gas chromatography [6]. Protein was measured by the biuret method of Weichselbaum [13].

Student's t-test was used to determine the statistical significance of differences between groups.

\section{Results}

Table 2 shows the sugar and polyol concentrations in sciatic nerve samples from the diabetic and control groups. Both free and lipid inositol concentrations were reduced by approximately $40 \%$ in the nerves of diabetic patients, while the protein contents were not significantly different. The reduction therefore cannot be accounted for by increased hydration of the diabetic samples. Seven of the diabetic patients included in the group of 23 had nerve inositol concentrations between 2.1 and $4.6 \mu \mathrm{mol} / \mathrm{g}$ tissue, while the others ranged between 0.3 and $1.8 \mu \mathrm{mol} / \mathrm{g}$. These seven patients were taking chlorpromazine or nitrazepam but we cannot be sure that these drugs affect inositol concentrations since many other drugs were being used in both groups and some of the control group were also taking these particular tranquilizers.

Concentrations of glucose, sorbitol and fructose were all greatly increased in the nerves of diabetic patients.

Inositol and glucose concentrations were not significantly different when nerves from patients treated with insulin and those receiving hypoglycaemic drugs were compared (Table 1).

\section{Discussion}

The results confirm earlier studies of peripheral nerve in experimental $[2,4,6]$ and human $[12,14]$ diabetes which showed increased concentrations of fructose and sorbi- tol. In contrast, there was a reduction in the free myoinositol concentration of nerves from diabetic patients. This has been observed in diabetic rats [4-7], though the changes now reported are more marked than those measured by the same methods in streptozotocin-treated animals [6]. In the only human study we are aware of [12], sural nerve biopsy gave a free inositol concentration very similar to our own for the control group, but diabetic patients were not significantly different. If anything, myo-inositol values were more often raised in nerves from the patients. The discrepancy is likely to be caused by differences in control of the diabetes. As our patients neared death, control will almost certainly have failed, as indicated by the higher fructose and sorbitol concentrations (Table 2) than those found in the biopsy samples. Dyck et al. [12] quote inositol concentrations more than double the normal for nerves from diabetic patients. Such high values suggest an error in their analytical methods.

Our lipid inositol values were significantly lower in the nerves from the diabetic patients and this supports the findings of Brown et al. [11] in sural nerve biopsy samples from three patients, though phosphatidylinositol and phosphatidylserine were analysed together.

Acknowledgements. We are grateful to Dr. A. M.J.Woolfson for his support and to Drs. C.W. Elston and J.S.P. Jones for advice and provision of nerves at post-mortem. The work was partly financed by a grant from the British Diabetic Association.

\section{References}

1. Clements Jr RS (1979) Diabetic neuropathy - new concepts of its etiology. Diabetes 28: 604-611

2. Gabbay KH (1973) Role of sorbitol pathway in neuropathy. In: Camerini-Davalos RA, Cole HS (eds) Vascular and neurologic changes in early diabetes. Academic Press, New York, pp 417-432

3. Jakobsen J (1978) Peripheral nerves in early experimental diabetes: expansion of the endoneurial space as a cause of increased water content. Diabetologia 14: 113-119

4. Stewart MA, Sherman WR, Kurien MM, Moonsammy GI, Wisgerhof M (1967) Polyol accumulation in nervous tissue of rats with experimental diabetes and galactosaemia. J Neurochem 14: 1057-1066

5. Greene DA, De Jesus PV, Winegrad AI (1975) Effects of insulin and dietary myoinositol on impaired peripheral nerve conduction velocities in acute streptozotocin diabetes. J Clin Invest 55: $1326-1336$

6. Palmano KP, Whiting PH, Hawthorne JN (1977) Free and lipid myoinositol in tissues from rats with acute and less severe streptozotocin-induced diabetes. Biochem $\mathrm{J}$ 167: 229-235

7. Clements Jr RS, Stockard CR (1980) Abnormal sciatic nerve myoinositol metabolism in the streptozotocin-diabetic rat. Effect of insulin treatment. Diabetes 29:227-235

8. White GL, Schellhase HU, Hawthorne JN (1974) Phosphoinositide metabolism in rat superior cervical ganglion, vagus and phrenic nerve: effects of electrical stimulation and various blocking agents. J Neurochem 22: 149-158

9. Hawthorne JN, Pickard MR (1979) Phospholipids in synaptic function. J Neurochem 32: 5-14

10. Servo C, Bergstrom L, Fogelholm R (1977) Cerebrospinal fluid sorbitol and myoinositol in diabetic polyneuropathy. Acta Med Scand 202: 301-304 
11. Brown MJ, Iwamori M, Kishimoto Y, Rapoport B, Moser HW, Asbury AK (1979) Nerve lipid abnormalities in human diabetic neuropathy: a correlative study. Ann Neurol 5:245-252

12. Dyck PJ, Sherman WR, Hallcher LM, Service FJ, O'Brien PC, Grina LA, Palumbo PJ, Swanson CJ (1980) Human diabetic endoneurial sorbitol, fructose and myoinositol related to sural nerve morphometry. Ann Neurol 8: 590-596

13. Weichselbaum TE (1946) An accurate and rapid method for the determination of proteins in small amounts of blood serum and plasma. Am J Clin Path 16: 40-49

14. Ward JD, Baker RWP, Davis BH (1972) Effect of blood sugar con- trol on the accumulation of sorbitol and fructose in nervous tissue. Diabetes 21: 1173-1178

Received: 9 March 1982

and in revised form: 13 July 1982

Professor J. N. Hawthorne

Department of Biochemistry

University Hospital and Medical School

Queen's Medical Centre

Nottingham NG7 2UH, UK 